\title{
Determining Impacts of Certification and Digitalization on Poverty of Smallholder Gayo Coffee Farmers in Indonesia
}

\author{
Wahyu Karami ${ }^{1}$, Musa Mustada ${ }^{1}$, Nonny S Navega ${ }^{1}$, Humam Hamid ${ }^{1,2}$, Agus Nugroho ${ }^{1,3, *}$ \\ ${ }^{1}$ Agribusiness Dept, Universitas Syiah Kuala, 23111, Banda Aceh, Indonesia \\ ${ }^{2}$ Center for Sustainable Agriculture and Rural Development, Universitas Syiah Kuala, 23111, Banda \\ Aceh Indonesia \\ ${ }^{3}$ Tsunami and Disaster Mitigation Research Center, Universitas Syiah Kuala, 23111, Banda Aceh, \\ Indonesia
}

\begin{abstract}
The benefit of global coffee certification schemes on farmers' economy is still arguable. A dynamic environment in voluntary standards and digitalization in the coffee trades has resulted in more complicated effects on the farmers' livelihood. This study aims to analyze the determining factors of certification schemes and digitalization on smallholder Gayo coffee farmers' livelihood. A total number of 488 Gayo coffee farmers located in eight sub-districts of Aceh Tengah and Bener Meriah Regencies of Aceh Province have been interviewed. A logit regression model was applied to determine the factors affecting farmers' poverty. This study found that in the "low management-low yields" coffee farmings, certification increases the income than the conventional coffees. However, the benefits only covered for farmer's basic expenditure in the short term. This study implies that the Gayo coffee certification schemes have less impacts on the adoption of technology and digitalization.
\end{abstract}

\section{Introduction}

Certification schemes on coffee production have been increasingly important [1-3] due to a growing worldwide demand for healthier, more socially, and environmentally friendly products [4]. Economically, it can be used to increase the value of selling coffee on the international market [5]. For example, the growth of organic coffee is associated with the turning down of the global coffee price during 2000-2004 [6].

The coffee price premium is the main idea behind the existing certified coffee schemes. Responsible consumers are willing to pay a higher price in order to contribute to more sustainable and fairer coffee trades. There are several generic certification schemes, e.g. organic, fair trade, UTZ, and 4C, and they differ in criteria, cost as well as price premium. Organic certification works to eliminate agrochemical use and to promote management practices that maintain soil fertility while others focus on the labor welfare of natural

\footnotetext{
*Corresponding author : nugroho@unsyiah.ac.id
} 
resource protection $[7,8]$. The main issue is that the relationship between price premiums and their impact on farmer welfare is a complex issue $[9,10]$.

Coffee production chains in the developing countries are more complex involving not only economic practices but also social, cultural, and institutional aspects [11-13]. The role of middlemen, both at the village and regional level, is very important $[11,14,15]$. These agents act as coffee collectors as well as production advisors, supply connectors, financial supporters, market stabilizers, and price-makers in the whole coffee chain. They have power, influence, and capital over coffee farmers. However, among these middlemen are also connected horizontally with other collectors (i.e., supply networks) and vertically with coffee companies, cooperatives, or exporters (i.e., capital networks).

The complexity in the coffee chain is the reason behind the certification awareness and in and out phenomenon of farmers toward certification schemes. The term certification awareness here refers to the understanding of farmers regarding their rights and obligations under the scheme. In practice, buyers or importers sign a contract with local certified coffee exporters, and then these exporters will ask collectors to arrange farmers under their networks to join a specific coffee certification scheme according to the contract. Farmers, depending on their level of education and experience, may not acquire thoroughly the information given by collectors, cooperatives, or exporters. This information gap leads to differences in farmers' expectations towards certification benefits. When the benefits differ from their expectation, farmers generally terminate their contract in the following year.

Another problem faced by coffee farmers is the lack of a caring attitude towards technological advances that can increase economic growth [16]. Although a study of farmers conducted in Bangladesh, China, India, and Vietnam found that 80 percent of farmers in these countries have cell phones and use them to connect with agents and traders to estimate market demand and selling prices [17], there are limited studies on how this digital advance interacts with certified coffee production [18].

This study aims to analyze the relationship between certification schemes, digitalization, and their impacts on coffee farmers' poverty. This study emphasizes that the traditional problem in coffee certification is actually nothing new. Therefore, this study suspects that there is a room available for digitalization to play more significant roles in enhancing information flows, reduce asymmetric information, and maintain sustainable relationships based on fairer trades and benefits of certification on coffee farmers' welfare.

\section{Method}

\subsection{Study Area and Household Survey}

This research was conducted in two coffee production regions known as Gayo Highland namely Bener Meriah and Aceh Tengah regencies of Aceh Province (Indonesia). Four subdistricts in each regency (Aceh Tengah: Kebayakan, Bebesen, Kute Panang, Jagong Jeged; Bener Meriah: Timang Gajah, Pintu Rime, Bandar, and Permata) were selected purposely based on their dominance in coffee production scales. A total of 487 coffee farmers were interviewed randomly between 01-31th July 2020 using structured questionnaires.

\subsection{Analysis Method}

There are two research questions to be examined in this study: 1) How does the relationship between farmer's willingness to coffee certification, technological advances, and their socioeconomics demographics?, and 2) To what extent recent digitalization may affect farmers' awareness on coffee certification? This study applies two approaches. First, the 
relationship between coffee certification, digitalization, and farmers' characteristics was modelled using multinomial logit regression. Second, this study applied descriptive statistics analysis to describe the relationship between digitalization and coffee certification schemes.

\section{Result and Discussion}

\subsection{Coffee Household Characteristic}

Table 1 shows the socio-demographic characteristics of the samples in our study. Three disaggregations were made based on the farmers' domicile, participatory in certification scheme, and type of coffee certification. The respondents reported that 211 farmers are active members and participated in coffee certification, and 276 others are conventional coffee producers. Out of 211 certified coffee farmers, fair trade accounts for 95 farmers, and the remaining 116 farmers are organic coffee producers.

The respondents in Aceh Tengah regency are dominantly by the male, older in terms of age, pose a higher degree of education, and a longer period of stays in their villages. This is relevant since Aceh Tengah is more developing regency than its neighboring regency, Bener Meriah. This study also found that, to some degree, farmers in Aceh Tengah are not relying completely on coffee. They have another occupation other than farmings for their incomes, so do higher expenses. In terms of computer literacy, there are more families in Aceh Tengah regency who are able to operate rather than the families in Bener Meriah regency. Farmers in Aceh Tengah typically got a higher sale price than farmers in Bener Meriah.

Table 1 shows some significant differences in the repondent' characteristics between certified and conventional coffee farmers. Certified coffee farmers are dominated by female in gender. The respondents tend to have additional occupation and have more knowledge to use the internet to find information related to coffee production and marketing. On average, certified organic farmers received higher prices than the fairtrade coffee farmers.

Table 1. Household sample characteristics

\begin{tabular}{|c|c|c|c|c|c|c|}
\hline \multirow[t]{2}{*}{ Variables } & \multicolumn{4}{|c|}{ Pooled sample } & \multicolumn{2}{|c|}{ Certification scheme } \\
\hline & $\begin{array}{l}\text { Aceh } \\
\text { Tengah }\end{array}$ & $\begin{array}{c}\text { Bener } \\
\text { Meriah }\end{array}$ & Certified & $\begin{array}{c}\text { Non- } \\
\text { certified }\end{array}$ & FT & Organic \\
\hline gender & $\begin{array}{l}1.616^{* * * *} \\
(0.487)\end{array}$ & $\begin{array}{l}1.334 \\
(0.473)\end{array}$ & $\begin{array}{l}1.573 * * * \\
(0.495)\end{array}$ & $\begin{array}{l}1.423 \\
(0.495)\end{array}$ & $\begin{array}{l}1.505 \\
(0.502)\end{array}$ & $\begin{array}{l}1.629 * \\
(0.485)\end{array}$ \\
\hline age & $\begin{array}{l}44.511 * \\
(11.30)\end{array}$ & $\begin{array}{l}42.583 \\
(11.707)\end{array}$ & $\begin{array}{l}44.431 \\
(10.729)\end{array}$ & $\begin{array}{l}43.028 \\
(12.06)\end{array}$ & $\begin{array}{l}44.326 \\
(11.310)\end{array}$ & $\begin{array}{l}44.517 \\
(10.27)\end{array}$ \\
\hline education & $\begin{array}{l}14.25 * * * \\
(4.459)\end{array}$ & $\begin{array}{l}12.312 \\
(5.182)\end{array}$ & $\begin{array}{l}4.976 \\
(2.281)\end{array}$ & $\begin{array}{l}5.079 \\
(2.259)\end{array}$ & $\begin{array}{l}4.789 \\
(2.268)\end{array}$ & $\begin{array}{l}5.129 \\
(2.289)\end{array}$ \\
\hline $\begin{array}{l}\text { year of } \\
\text { stay }\end{array}$ & $\begin{array}{l}30.383 * \\
(15.900)\end{array}$ & $\begin{array}{l}27.665 \\
(16.41)\end{array}$ & $\begin{array}{l}31.43 * * * \\
(14.609)\end{array}$ & $\begin{array}{l}27.405 \\
(17.09)\end{array}$ & $\begin{array}{l}31.884 \\
(14.512)\end{array}$ & $\begin{array}{l}31.060 \\
(14.74)\end{array}$ \\
\hline main job & $\begin{array}{l}1.154 * * * \\
(0.361)\end{array}$ & $\begin{array}{l}1.072 \\
(0.259)\end{array}$ & $\begin{array}{l}1.118 \\
(0.323)\end{array}$ & $\begin{array}{l}1.115 \\
(0.320)\end{array}$ & $\begin{array}{l}1.105 \\
(0.308)\end{array}$ & $\begin{array}{l}1.129 \\
(0.336)\end{array}$ \\
\hline side job & $1.665^{* * *}$ & 1.443 & 1.592 & 1.543 & 1.515 & $1.655^{* *}$ \\
\hline
\end{tabular}




\begin{tabular}{|l|l|l|l|l|l|l|} 
& $(0.472)$ & $(0.497)$ & $(0.492)$ & $(0.499)$ & $(0.502)$ & $(0.477)$ \\
\hline $\begin{array}{l}\text { house } \\
\text { structure }\end{array}$ & $\begin{array}{l}1.706 \\
(0.586)\end{array}$ & $\begin{array}{l}1.710 \\
(0.665)\end{array}$ & $\begin{array}{l}1.658 \\
(0.575)\end{array}$ & $\begin{array}{l}1.746 \\
(0.655)\end{array}$ & $\begin{array}{l}1.652 \\
(0.614)\end{array}$ & $\begin{array}{l}1.663 \\
(0.542)\end{array}$ \\
\hline $\begin{array}{l}\text { number of } \\
\text { family }\end{array}$ & $\begin{array}{l}4.165 \\
(1.280)\end{array}$ & $\begin{array}{l}4.294 \\
(1.507)\end{array}$ & $\begin{array}{l}4.241 \\
(1.415)\end{array}$ & $\begin{array}{l}4.210 \\
(1.369)\end{array}$ & $\begin{array}{l}4.189 \\
(1.169)\end{array}$ & $\begin{array}{l}4.284 \\
(1.592)\end{array}$ \\
\hline Expense & $\begin{array}{l}75349.62 * * \\
(46352)\end{array}$ & $\begin{array}{l}85633.48 \\
(45262)\end{array}$ & $\begin{array}{l}81099.53 \\
(44261)\end{array}$ & $\begin{array}{l}79188.41 \\
(47520)\end{array}$ & $\begin{array}{l}80989.47 \\
(35418)\end{array}$ & $\begin{array}{l}81189.66 \\
(50517)\end{array}$ \\
\hline Income & $\begin{array}{l}4149049 \\
(2705191)\end{array}$ & $\begin{array}{l}3911244 \\
(3087957)\end{array}$ & $\begin{array}{l}4124768 \\
(2693858)\end{array}$ & $\begin{array}{l}3977196 \\
(3025570)\end{array}$ & $\begin{array}{l}3961853 \\
(2696336)\end{array}$ & $\begin{array}{l}4258190 \\
(2696140)\end{array}$ \\
\hline $\begin{array}{l}\text { computer } \\
\text { literacy in } \\
\text { family }\end{array}$ & $\begin{array}{l}1.150^{*} \\
(1.237)\end{array}$ & $\begin{array}{l}0.959 \\
(1.121)\end{array}$ & $\begin{array}{l}1.033 \\
(1.176)\end{array}$ & $\begin{array}{l}1.086 \\
(1.199)\end{array}$ & $\begin{array}{l}0.968 \\
(0.972)\end{array}$ & $\begin{array}{l}1.086 \\
(1.322)\end{array}$ \\
\hline $\begin{array}{l}\text { internet } \\
\text { literacy in } \\
\text { family }\end{array}$ & $\begin{array}{l}1.646 \\
(1.330)\end{array}$ & $\begin{array}{l}(1.656 \\
(1.378)\end{array}$ & $\begin{array}{l}1.691 \\
(1.325)\end{array}$ & $\begin{array}{l}1.619 \\
(1.371)\end{array}$ & $\begin{array}{l}1.652 \\
(1.089)\end{array}$ & $\begin{array}{l}1.724 \\
(1.495)\end{array}$ \\
\hline $\begin{array}{l}\text { internet } \\
\text { experience }\end{array}$ & $\begin{array}{l}1.744 \\
(0.437)\end{array}$ & $\begin{array}{l}1.696 \\
(0.460)\end{array}$ & $\begin{array}{l}1.739 \\
(0.440)\end{array}$ & $\begin{array}{l}1.710 \\
(0.454)\end{array}$ & $\begin{array}{l}1.694 \\
(0.462)\end{array}$ & $\begin{array}{l}1.775 \\
(0.418)\end{array}$ \\
\hline $\begin{array}{l}\text { internet for } \\
\text { marketing }\end{array}$ & $\begin{array}{l}1.090 \\
(0.287)\end{array}$ & $\begin{array}{l}1.095 \\
(0.293)\end{array}$ & $\begin{array}{l}1.127 * * \\
(0.334)\end{array}$ & $\begin{array}{l}1.065 \\
(0.247)\end{array}$ & $\begin{array}{l}1.105 \\
(0.308)\end{array}$ & $\begin{array}{l}1.146 \\
(0.355)\end{array}$ \\
\hline $\begin{array}{l}\text { mobile } \\
\text { banking } \\
\text { experience }\end{array}$ & $\begin{array}{l}2.334 \\
(0.845)\end{array}$ & $\begin{array}{l}2.325 \\
(0.793)\end{array}$ & $\begin{array}{l}2.298 \\
(0.822)\end{array}$ & $\begin{array}{l}2.355 \\
(0.820)\end{array}$ & $\begin{array}{l}2.178 \\
(0.635)\end{array}$ & $\begin{array}{l}2.396 * \\
(0.940)\end{array}$ \\
\hline sale price & $\begin{array}{l}8274 * * * \\
(106.59)\end{array}$ & $\begin{array}{l}7805 \\
(118.83)\end{array}$ & $\begin{array}{l}8004.739 \\
(120.65)\end{array}$ & $\begin{array}{l}8105.072 \\
(106.93)\end{array}$ & $\begin{array}{l}7726 \\
(182.33)\end{array}$ & $\begin{array}{l}7805 * * \\
(118.83)\end{array}$ \\
\hline
\end{tabular}

\subsection{Estimation Result}

The analysis begins with evaluating the determining factors of household participation in certification scheme. Two multinomial logit regression models were applied.The first model used a willingnes to join in certification scheme (table 2) and the second model used the internet literacy for the dependent variable (table 3). A broad range of explanatory variables such as socioeconomic demographics and experience in digitalization were included. The certification decision may be influenced by the individual characteristics, such as gender, age, number of dependents, education, and farming experience.

Each certification scheme requires different cultivation practices; therefore, proxies such as land size, land ownership, total production, and sale price were expected to have significant influences. Furthermore, knowledge in digitalization such as computer and internet literacy, as well as cell phone ownerships, may also influence farmers' decision on certification. 
Tabel 2. Logit regression result of willingness to join in coffee certification

\begin{tabular}{|l|l|l|l|}
\hline parameters & $\begin{array}{l}\text { Dep Var: } \\
\text { Certification }\end{array}$ & Dep Var: FT & Dep Var: OR \\
\hline age & $-.003(.010)$ & $.001(.012)$ & $-.005(.011)$ \\
\hline gender & $.642 * * *(.200)$ & $.067(.032)$ & $.751 * * *(.223)$ \\
\hline land size & $.274 * *(.121)$ & $.050(.109)$ & $.074(.103)$ \\
\hline experience & $.026^{* *}(.010)$ & $.0087(.012)$ & $.015(.011)$ \\
\hline number of dependant & $-.135 *(.077)$ & $-.027(.089)$ & $-.009(.083)$ \\
\hline cons & $-.546(.531)$ & $-1.724 * * *(.625)$ & $-2.48 * * *(.601)$ \\
\hline $\begin{array}{l}* \mathrm{p}<0.1 ; * * \mathrm{p}<0.05 ; \\
* * * \mathrm{p}<0.01\end{array}$ & $\begin{array}{l}\mathrm{N} \text { of obs }=487 \\
\text { Log likelihood }= \\
-298.68887\end{array}$ & $\begin{array}{l}\mathrm{N} \text { of obs }=487 \\
\text { Log likelihood }=- \\
239.68188\end{array}$ & $\begin{array}{l}\text { Lof obs }=487 \\
259.93529\end{array}$ \\
\hline
\end{tabular}

This study presents only the factors having statistically significant in the estimation results and provide a brief detail in factors that have insignificant influences on farmers' participation in the certification schemes. The gender of the respondents does influence participation in the certification schemes, particularly in organic, suggesting that certification practice is closely related to this variable. Females respondents are more likely to be organic, certified participants. The likelihood of joining certification is also greater when land size is larger, and the year of coffee cultivation experience is longer. However, those variables, including age and number of dependents, do not influence the likelihood of Fairtrade

Table 3. Logit regression result of internet literacy

\begin{tabular}{|l|l|l|}
\hline Parameters & $\begin{array}{l}\text { Dep Var: Internet } \\
\text { literacy }\end{array}$ & $\begin{array}{l}\text { Dep Var: Internet for } \\
\text { Marketing }\end{array}$ \\
\hline Education & $\begin{array}{l}.1079 * * * \\
(.0255)\end{array}$ & $\begin{array}{l}.0723 * \\
(.0424)\end{array}$ \\
\hline Age & $\begin{array}{l}-.0435 * * * \\
(.0109)\end{array}$ & $\begin{array}{l}-.0359 * * \\
(.0169)\end{array}$ \\
\hline Gender & $\begin{array}{l}1.077 * * * \\
(.2474)\end{array}$ & $\begin{array}{l}.0003 \\
(.3376)\end{array}$ \\
\hline $\begin{array}{l}\text { Number family member able } \\
\text { to access the internet }\end{array}$ & $\begin{array}{l}.8337 * * * \\
(.1537)\end{array}$ & $\begin{array}{l}.3647 * * \\
(.1500)\end{array}$ \\
\hline $\begin{array}{l}\text { Number family member able } \\
\text { to operate a computer }\end{array}$ & $\begin{array}{l}.522 * * * \\
(.1616)\end{array}$ & $\begin{array}{l}.1887 \\
(.1647\end{array}$ \\
\hline $\begin{array}{l}* p<0.1 ; * * p<0.05 ; \\
* * * p<0.01\end{array}$ & $\begin{array}{l}\text { Nof obs }=487 \\
227.07895\end{array}$ & $\begin{array}{l}\text { N of obs }=487 \\
\text { Log-likelihood }=- \\
131.95401\end{array}$ \\
\hline
\end{tabular}


This study have expected that limited statistically significant variables would be available on our result since the distinction between certified and conventional coffee becomes narrowing in the study area. Then, this study are interested in the current development of digitalization in coffee productions. Our study found a very low rate of internet literacy ratio, which is only 27,72 percent. Table 3 shows a multinomial logit regression result of factors influencing digitalization on coffee farmings. Year of schooling seems a valid factor that increases the likelihood of internet understanding as well as the use of the internet for coffee marketing. Millennial farmers tend to use the internet more frequently in comparison to their parents, and so do male respondents. Families in which the member has greater numbers in computer ability or internet connection also tend to be more familiar with the digitalization of coffee production.

Figure 1 describes the statistics of internet application in coffee production in the two regencies. There is a greater ratio of "neutral," "don't know," and "useful" answers among the respondents. Basically, coffee farmers in Aceh Tengah regency tend to be higher in internet openness and application in their coffee production and marketing. The respondents reported that the internet is useful for finding information related to coffee cultivation $(\mathrm{BM}=24.92 \%$; $\mathrm{AT}=32.97 \%)$. They also reported that the internet is useful for sharing information among the coffee farmers $(\mathrm{BM}=15.12 \%$; $\mathrm{AT}=25.39 \%)$. The study found a smaller percentage in the answer related to the benefits of the internet on farmer's income $(\mathrm{BM}=11.11 \% ; \mathrm{AT}=19.5 \%)$. Most of the respondents mentioned that they never make a payment through mobile banking $(\mathrm{BM}=71.9 \%$; $\mathrm{AT}=69.24 \%)$.

\begin{tabular}{|l|l|}
\hline & \\
\hline
\end{tabular}

Fig.1. Application of internet in the coffee production in Aceh Tengah 


\subsection{Discussion}

This study strongly believes that female farmers play an important role in coffee certification schemes. In practice, this study found that coffee cultivations e.g. seed planting, weed clearing, fertilizing, and harvesting, are maintained by the housewives. The head of the family (normally males) then makes decisions on how to sell the coffee and the coffee sale price. As for other factors, this study found that most of the variables are not statistically significant. Age, status in the family (female-headed $\mathrm{HH}$ ), education, main job (agriculture $=1$; non agriculture $=0$ ), and house structure (permanent $=1$; non permanent $=0$ ) have no significant influence on the certified coffee participation. These findings indicate that the historical certification practices in Aceh Tengah and Bener Meriah have been dynamically converged. There is no clear distinction between conventional and certified coffees.

Furthermore, this study argues that the participation of coffee farmers in certification schemes does not affect their welfare because the coffee selling price is slightly similar between certified and conventional coffees. The certified coffee members received the premiums in the form of capacity-building assistance in coffee production, agricultural equipment, and the improvement of coffee estate infrastructure. There is no direct assistance to raise farmers' welfare standards significantly.

In terms of cell phones, internet, and computers application, the utility of these digital advances is still very low. Sending SMS and calls are more preferred due to poor internet connection quality. The communication between farmers and local coffee collectors is very helpful since both parties tend to maximize efficiency in their working time to obtain supplies with good quality of the coffee. Farmers who are more familiar with smartphones have a wider market network and make them more effective and efficient in marketing coffee and getting cash quickly. Some coffee farmers took advantage of the digitalization by selling higher value-added products online using the internet.

\section{Conclusion}

Coffee production in Gayo highland has uniquely achieved its convergence, making it difficult to distinguish between the conventional and certified coffee. The difference in prices is not reflected in the coffee cultivation criteria due to in and out in the certification schemes phenomenon. The extra prices of certified coffee provide short term benefits, however it is not sustainable for the long term. Technology and digitalization as a tool to to improve coffee farmers' livelihood have not been utilized due to lack of awareness. This study implies that Gayo coffees certification schemes failed to encourage the adoption of technology and digitalization.

Acknowledgement. The authors would like to acknowledge the funding support from The Ministry of Education and Culture and Universitas Syiah Kuala under the scheme Professor Research Grant for the year 2020 with the contract number: 268/UN11/SPK/PNBP/2020.

\section{References}

1. B. L. Barham and J. G. Weber, World Dev., 40, 6, pp. 1269-1279, (2012).

2. B. Minten, M. Dereje, E. Engida, and S. Tamru, World Dev., 101, pp. 119-132, (2018).

3. F. Mitiku, Y. De Mey, J. Nyssen, and M. Maertens, Sustainability, 9, 2, p. 246, (2017).

4. A. Nugroho, Procedia Environ. Sci., 20, pp. 425-433, (2014). 
5. A. Wahyudi, S. Wulandari, A. Aunillah, and J. C. Alouw, IOP Conference Series: Earth and Environmental Science, 418, 1, p. 12009, (2020).

6. J. Valkila, Ecol. Econ., 68, 12, pp. 3018-3025, (2009).

7. J. Vandermeer, Annu. Rev. Ecol. Syst., 26, 1, pp. 201-224, (1995).

8. S. M. Philpott, P. Bichier, R. Rice, and R. Greenberg, Conserv. Biol., 21, 4, pp. 975985, (2007).

9. C. Bacon, World Dev., 33, 3, pp. 497-511, (2005).

10. B. Daviron and S. Ponte, Zed books, (2005).

11. J. Potts, IISD UNCTAD, Geneva, (2003).

12. M. E. Blowfield and C. Dolan, J. Bus. ethics, 93, 2, pp. 143-162, (2010).

13. J. Valkila, P. Haaparanta, and N. Niemi, J. Bus. ethics, 97, 2, pp. 257-270, (2010).

14. S. B. Bush, Springer, (2012).

15. J. L. Guasch and R. Polastri, An Oppor. a Differ., p. 215, (2007).

16. F. Hasan, M. H. Rahman, M. J. Hoque, K. Kamruzzaman, and M. Azizur, J. Biosci. Biotechnol, 4, 1, pp. 34-47, (2019).

17. T. Reardon, C. P. Timmer, and B. Minten, Proc. Natl. Acad. Sci., 109, 31, pp. 1233212337, (2012).

18. E. S. A. S. A. A. Offermans and P. Glasbergen, J. Econ. Sustain. Dev, 6, 24, pp. 84-98, (2015). 